\title{
Prospect of squalls ahead
}

THE heads of Britain's five scientific research councils have temporarily shelved their differences to make an unprecedented plea to the government for a substantial increase in next year's science budget. They say that valuable new scientific opportunities are being lost because the government's "level funding" policy takes no account of the rising costs of scientific instrumentation and raw materials.

The plea is made in a paper drawn up by the research council heads under the chairmanship of Professor John Kingman of the Science and Engineering Research Council. The paper was due to be discussed this week at a meeting of the Advisory Board for the Research Councils as the first stage of its annual survey of scientific opportunities, when it will argue the case for an increased science budget in order to give the Secretary of State for Education and Science, Sir Keith Joseph, ammunition for battles within the government over public expenditure priorities.

Last year, the research council heads each made separate bids for support of important new developments in their own areas. That was entirely unsuccessful: the $£ 27$ million extra they requested was flatly turned down, and the only increase in real terms was earmarked to meet the rising cost of international subscriptions. As a consequence they have this year sought strength in numbers by throwing their lots in together.

The government's case is that the size of the science budget ( $£ 550$ million in the coming financial year) has been roughly maintained in real terms, and that Britain must retain its high standing by making savings in less important areas and by increasing efficiency. But the research council heads emphasize that the extra five per cent on top of the existing science budget that would be needed for new areas to be exploited cannot be found by increasing efficiency or by diverting funds from other areas.

Sir Hermann Bondi, chairman of the Natural Environment Research Council, says that while he is willing to divert "a few millions" into priority areas, it is impossible to achieve savings to meet the costs of space-based research, which are of "a different order of magnitude" from conventional scientific activity. This "sophistication factor" applies also to Earth-based instruments as they become computerized, says Sir Hermann. He stresses that science is an "internationally competitive business" and that the United States, France and Japan are all sharply increasing the levels of financial support for science. Britain's continued participation in the extension of the International Deep Sea Drilling Project is still in doubt due to pressure on funds.

Both the Science and Engineering
Research Council and the Natural Environment Research Council are worried about the steep drop in the proportion of project grant applications deemed to be of "alpha" merit that they are turning down on cost grounds. In engineering, for example, some 40 per cent of alpha-grade applications are now being refused. And there is increasing concern that Britain is relying for space-based work on the charity of other nations. The Science and Engineering Research Council argues that in order to maintain its international standing, Britain must at least occasionally lead a satellite programme. But at present there appears to be little chance of that happening.

The Medical Research Council is also hard hit by increasing costs (see p.304). Plastics and restriction enzymes are cited as examples of essentials that are increasing in cost faster than inflation. Pay increases to staff based in universities and to civil servants have exceeded the allowances made for them and are outside the control of the individual councils. The rising cost of pension contributions (which have to be paid for out of the research councils' budgets) is another obligation which reduces the value of the science budget and which is likely to increase. The council would be one of four that would collaborate in a $£ 4$ million initiative on biotechnology if funds were available.

The Advisory Board for the Research Councils will include the research heads' document in its advice to Sir Keith next month. But once the likely size of the 1985-86 science budget becomes known, the temporary alliance may come to an abrupt end as the councils fight to decide how the cake will be divided between them. Last year's advice on the division of the science budget is due to be published, belatedly, this week. Participants in the exercise are preparing themselves for some close questioning on their priorities.

Tim Beardsley

\section{Polish academics}

\section{Nuclear institute still disfavoured}

POLISH scientists who worked at the former Institute of Nuclear Physics (IBJ) at Swierk outside Warsaw are said to have rejected a bargain that could have led to the reinstatement of a number of scientists dismissed during the martial law period. During the winter of 1982-83, the institute was closed down and divided into three.

Several independent reports reached Nature at that time that at least 40 researchers who had held tenured positions lost their jobs and that those affected were for the most part former activists of Solidarity.

According to the underground Solidarity press, the Party authorities intimated at the end of last year that they were prepared to "reconsider the question" if the Swierk scientists would undertake certain "political initiatives":

- To draft and sign a statement condemning the siting of Cruise and Pershing missiles in Western Europe. (This must be signed by not fewer than 40 persons holding the degree of Doctor Habilitatus.) - To "deny in Nature" (presumably by means of a letter to the correspondence page) the article published in 1983.

- To exert influence to counteract "terrorist actions" on the premises of the former IBJ.

\section{DESMOND on line}

THE development of computer acronyms will pass another milestone this week when the Open University in the United Kingdom unveils its new educational machine DESMOND - the Digital Electronic System Made Of Nifty Devices.
- To write, for example in Polityka, the influential weekly paper, an article "to be based on material supplied by the Central Committee's Science Department" appraising "in the correct manner" those physicists who have gone on official trips abroad and then stayed in the West.

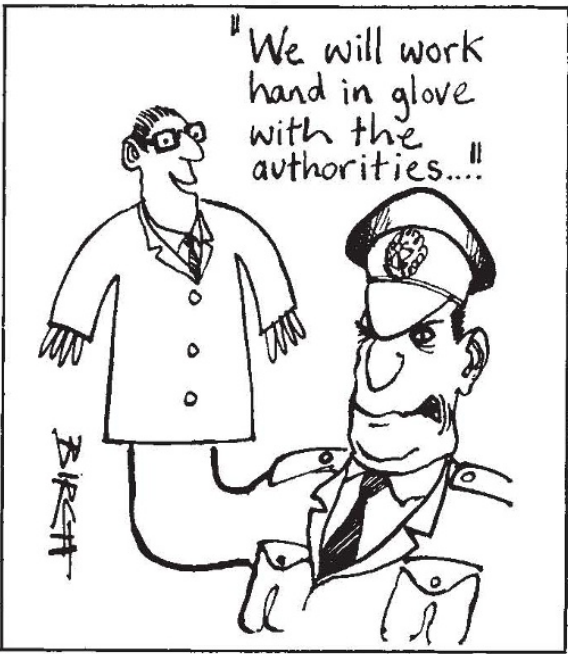

The "terrorist actions" referred to in this list refer, presumably, to the strike at Swierk in protest against the imposition of martial law in December 1981, and the possibility of further protests by Solidarity supporters at the institute.

According to the underground press, the Swierk scientists have refused to comply with the proposed "initiatives" on the grounds that the authorities have no right to make such demands.

Nature would, of course, be delighted to reassure its readers that all is well at Swierk - as soon as clear evidence is available that this is indeed so.
Vera Rich 